\title{
Chromosomal characterization of Hyla bischoffi and Hyla guentheri (Anura, Hylidae)
}

\author{
Simone C. Raber ${ }^{1}$, Klélia A. Carvalho ${ }^{1}$, Paulo C. A. Garcia ${ }^{2}$, Giovanni Vinciprova ${ }^{3}$ and \\ Shirlei M. Recco-Pimentel ${ }^{1}$ \\ 1 Departamento de Biologia Celular, Instituto de Biologia, Universidade Estadual de Campinas, 13083-863, \\ Campinas, SP, Brazil. E-mail: shirlei@unicamp.br. \\ 2 Centro de Ciências da Saúde, Universidade de Mogi das Cruzes, 08780-911, Mogi das Cruzes, SP, Brazil. \\ 3 Departamento de Zoologia, Universidade Federal do Rio Grande do Sul, 90046-900, Porto Alegre, RS, Brazil.
}

\begin{abstract}
Chromosomal characterization of Hyla bischoffi and Hyla guentheri (Anura, Hylidae). Hyla bischoffi and H. guentheri share some morphological and call characters with the $H$. pulchella and $H$. polytaenia groups. The inclusion of these two species in one of these two groups is still controversial. This study showed that both species have $2 n=24$ chromosomes, consisting of five metacentric, five submetacentric, and two subtelocentric chromosome pairs. The nucleolus organizer region (NOR) was located on the long arm of chromosome 10, which also presented a block of heterochromatin in both species. The pericentromeric region of all the chromosomes was positively $\mathrm{C}$-banded. There were no conspicuous differences in the karyotypes of these two species, except for an additional heterochromatic C-band on the short arms of chromosome 6 in $H$. bischoffi. The karyotypes of these two species were very similar to those of the $H$. pulchella group and indicate that neither species can be excluded from that group.
\end{abstract}

Keywords: Anura, Hylidae, Hyla bischoffi, Hyla guentheri, chromosomes, karyotype, cytogenetics.

\section{Introduction}

The genus Hyla Laurenti, 1768 comprises a large number of species that are organized in groups, according to their morphological similarities. These groups are relevant to the definition of monophyletic units (Cruz and Caramaschi 1998). However, some species have

Received 5 January 2004.

Accepted 12 May 2004.

Distributed 30 September 2004. characters that make it difficult to allocate them to any of the currently recognized groups. Hyla bischoffi Boulenger, 1887 and H. guentheri Boulenger, 1886 are examples of this situation.

In the original description, $H$. bischoffi was associated with $H$. pulchella Duméril and Bibron, 1841, and the two species were even assumed to be the same in different collections (Lutz 1973). Later, both species were included in the $H$. albopunctata group by Cochran (1955), who recognized two subspecies, $H$. bischoffi bischoffi in the Brazilian states of Rio 
Grande do Sul and Santa Catarina, and Hyla bischoffi multilineata Lutz and Lutz, 1939 in the state of São Paulo. Lutz (1973) confirmed the classification of the two subspecies and included them in the $H$. polytaenia group. Heyer et al. (1990) recognized a population found in Boracéia as $H$. multilineata but disregarded its status in relation to $H$. b. bischoffi. Haddad and Sazima (1992) disagreed with this classification and considered that the morphological differences between the two subspecies were insufficient to differentiate the two populations, classifying both of them as Hyla bischoffi.

Hyla guentheri Boulenger, 1886 was included by Lutz (1973) in the H. polytaenia group on the basis of its dorsal color pattern. This was also considered a relevant character by Braun and Braun (1977, 1980). However, Klappenbach and Langone (1992) and Langone (1997) considered that $H$. guentheri, with its type locality in Rio Grande do Sul, could be included in the $H$. pulchella group based on certain morphological characters. Furthermore, there is similarity between the vocalization pattern of this species and that of others of the same group (P. C. A. Garcia, unpublished data). Langone (1997) concluded that it was not possible to decide to which group this species belonged due to the lack of clear distinctions between the $H$. pulchella and $H$. polytaenia groups at that time.

Duellman et al. (1997) redefined the $H$. pulchella group and did not include the species $H$. bischoffi and $H$. guentheri because they lack hypertrophic forearms, a marked character of the group. Cruz and Caramaschi (1998) defined the $H$. polytaenia group as containing four species (H. polytaenia, H. goiana, H. cipoensis, and $H$. leptolineata) easily distinguished from $H$. bischoffi and $H$. guentheri by the absence of strips or rounded spots in the hidden parts of the thighs and inguinal region. Hyla bischoffi and $H$. guentheri are therefore currently not included in either of the two groups (polytaenia or pulchella), despite their apparent relatedness to both groups. Recently, morphological (Garcia
2003) and molecular analysis (Faivovich et al. in press) suggested that $H$. bischoffi and $H$. guentheri should be included in the $H$. pulchella group.

There is little cytogenetic data on the species associated with the $H$. pulchella and $H$. polytaenia groups. Ananias (1996) and Ananias et al. (2004) studied the karyotype, pattern of heterochromatin and nucleolus organizer region distribution in some species of the $H$. pulchella group. In the $H$. polytaenia group, only the karyotype of $H$. polytaenia polytaenia has been described (Rabello 1970).

In this paper, we examined the chromosomes of $H$. bischoffi and $H$. guentheri to obtain cytogenetic information that might help in the classification of these two species, particularly in defining their relationship to other groups of Hyla.

\section{Material and Methods}

All frogs were collected in the states of Rio Grande do Sul (RS) and Santa Catarina (SC), southern Brazil: eight specimens of $H$. bischoffi (all males) from São Francisco de Paula, six (all males) from Rancho Queimado, and eight specimens of $H$. guentheri (seven males and one female) from Terra de Areia. Hyla bischoffi was found in perennial ponds in open areas or, more frequently, on forest edges in mountain areas above $800 \mathrm{~m}$ altitude. Hyla guentheri was collected in temporary puddles inside swamp forest in the coastal region at about $100 \mathrm{~m}$ altitude. Specimens were deposited in the ZUEC collection ("Professor Adão José Cardoso") Museu de História Natural of the Universidade Estadual de Campinas (accession numbers 11731-11738: H. guentheri) and in the CFBH collection of the Departmento de Zoologia of the Universidade Estadual Paulista at Rio Claro (accession numbers CFBH 3335-3360, 3676-3683: H. b. bischoffi), state of São Paulo, Brazil.

The chromosomal preparations were obtained from suspensions of intestinal epithe- 
Table 1 - Morphometric analysis of the mitotic chromosomes of Hyla b. bischoffi and H. guentheri. The values are the mean of measurements for 32 metaphases of $H$. b. bischoffi and for 44 metaphases of $H$. guentheri. RS, relative size (\%); AR, arm ratio; $\mathrm{CI}$, centromeric index; $\mathrm{CP}$, centromere position; $\mathrm{M}$, metacentric; SM, submetacentric; ST, subtelocentric.

\begin{tabular}{|c|c|c|c|c|c|c|c|c|c|c|c|c|}
\hline \multicolumn{13}{|c|}{ Chromosomes } \\
\hline & 1 & 2 & 3 & 4 & 5 & 6 & 7 & 8 & 9 & 10 & 11 & 12 \\
\hline \multicolumn{13}{|c|}{ Hyla guentheri } \\
\hline $\mathrm{RS}(\%)$ & 17.48 & 13.55 & 10.69 & 10.68 & 9.59 & 8.06 & 6.44 & 5.58 & 5.53 & 4.99 & 4.35 & 3.29 \\
\hline $\mathrm{AR}$ & 1.02 & 1.28 & 1.88 & 3.36 & 1.74 & 3.07 & 2.11 & 1.07 & 2.11 & 2.05 & 1.00 & 1.00 \\
\hline $\mathrm{CI}$ & 0.49 & 0.43 & 0.35 & 0.23 & 0.36 & 0.24 & 0.32 & 0.48 & 0.32 & 0.33 & 0.50 & 0.50 \\
\hline $\mathrm{CP}$ & $\mathrm{M}$ & $\mathrm{M}$ & SM & $\mathrm{ST}$ & $\mathrm{SM}$ & $\mathrm{ST}$ & $\mathrm{SM}$ & $\mathrm{M}$ & $\mathrm{SM}$ & $\mathrm{SM}$ & $\mathrm{M}$ & $\mathrm{M}$ \\
\hline \multicolumn{13}{|c|}{ Hyla b. bischoffi } \\
\hline RS (\%) & 17.48 & 13.48 & 10.98 & 10.79 & 9.84 & 7.97 & 6.27 & 5.54 & 5.20 & 4.90 & 4.25 & 3.39 \\
\hline AR & 1.10 & 1.50 & 2.01 & 3.60 & 2.17 & 3.49 & 2.12 & 1.11 & 1.86 & 1.83 & 1.02 & 1.00 \\
\hline CI & 0.47 & 0.40 & 0.33 & 0.22 & 0.32 & 0.23 & 0.32 & 0.47 & 0.35 & 0.35 & 0.49 & 0.50 \\
\hline $\mathrm{CP}$ & $\mathrm{M}$ & M & SM & ST & $\mathrm{SM}$ & $\mathrm{ST}$ & $\mathrm{SM}$ & $\mathrm{M}$ & $\mathrm{SM}$ & $\mathrm{SM}$ & $\mathrm{M}$ & $\mathrm{M}$ \\
\hline
\end{tabular}

lial and testis cells of frogs treated with colchicine for at least four hours, as described by Schmid (1978) and Schmid et al. (1979), followed by conventional staining with $10 \%$ Giemsa solution in phosphate buffer at $\mathrm{pH}$ 7.0. The chromosomes were classified according to Green and Sessions (1991). Thirty-two metaphases of Hyla bischoffi and 44 of $H$. guentheri were measured to classify the chromosomes and to construct the idiograms. C-banding followed Sumner (1972) and Schmid (1982), with a few modifications that included variation in the incubation times with $\mathrm{Ba}(\mathrm{OH})_{2}$ and $2 \mathrm{xSSC}$ solutions. The Ag-NOR procedure of Howell and Black (1980) was used to localize the NORs.

\section{Results}

Both Hyla bischoffi and H. guentheri showed $2 \mathrm{n}=24$ chromosomes and a karyotype with six large and six small chromosomal pairs. Chromosomes 1, 2, 8, 11 and 12 metacentric; chromosomes 3, 5, 7, 9 and 10 submetacentric and chromosomes 4 and 6 were subtelocentric (Figures 1 and 3, Table 1). Chromosome 10 consistently showed a secondary constriction intertitially on the long arm in all preparations (Figure 1).

The chromosomes of the two species showed pericentromeric heterochromatin in all chromosomes and a conspicuous positive $\mathrm{C}$ block on the long arm of chromosome 10 , adjacent to a secondary constriction. Both species also presented a telomeric C-band that was clearly identified on the long arm of chromosome 1 (Figures 2 and 3). In addition, darkly stained heterochromatin extending over almost the entire short arm of chromosome 6 of H. bischoffi was detected (Figures $2 \mathrm{~B}$ and $3 \mathrm{~B}$ ). 

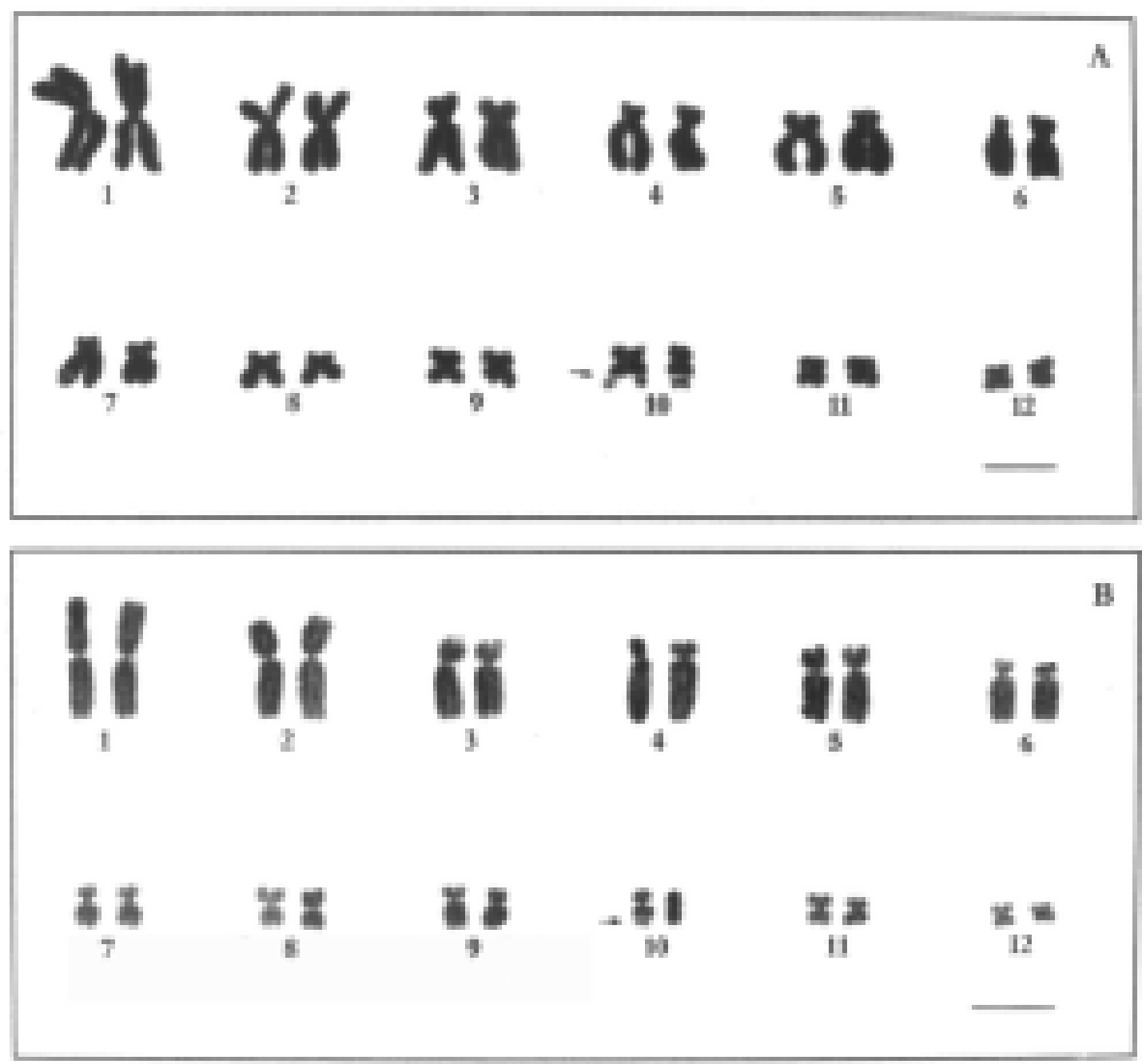

Figure 1 - Karyotypes of Hyla guentheri (A) and H. b. bischoffi (B). Giemsa-stained mitotic metaphases of intestinal epithelial cells. Bar $=5 \mathrm{~mm}$.

Both species of Hyla presented the AgNORs at the long arm of chromosome 10, coincident with the secondary constriction (Figures 2 and 3). Sequential staining with Cbanding and silver impregnation revealed that the NOR did not coincide with the heterochromatin but was adjacent to it.

\section{Discussion}

Diploid number of chromosomes of $2 \mathrm{n}=24$ found in $H$. bischoffi and $H$. guentheri was the same as that of H. b. multilineata (Beçak 1968), H. b. bischoffi (Foresti 1972), H. polytaenia (Rabello 1970) and other species of the $H$. 


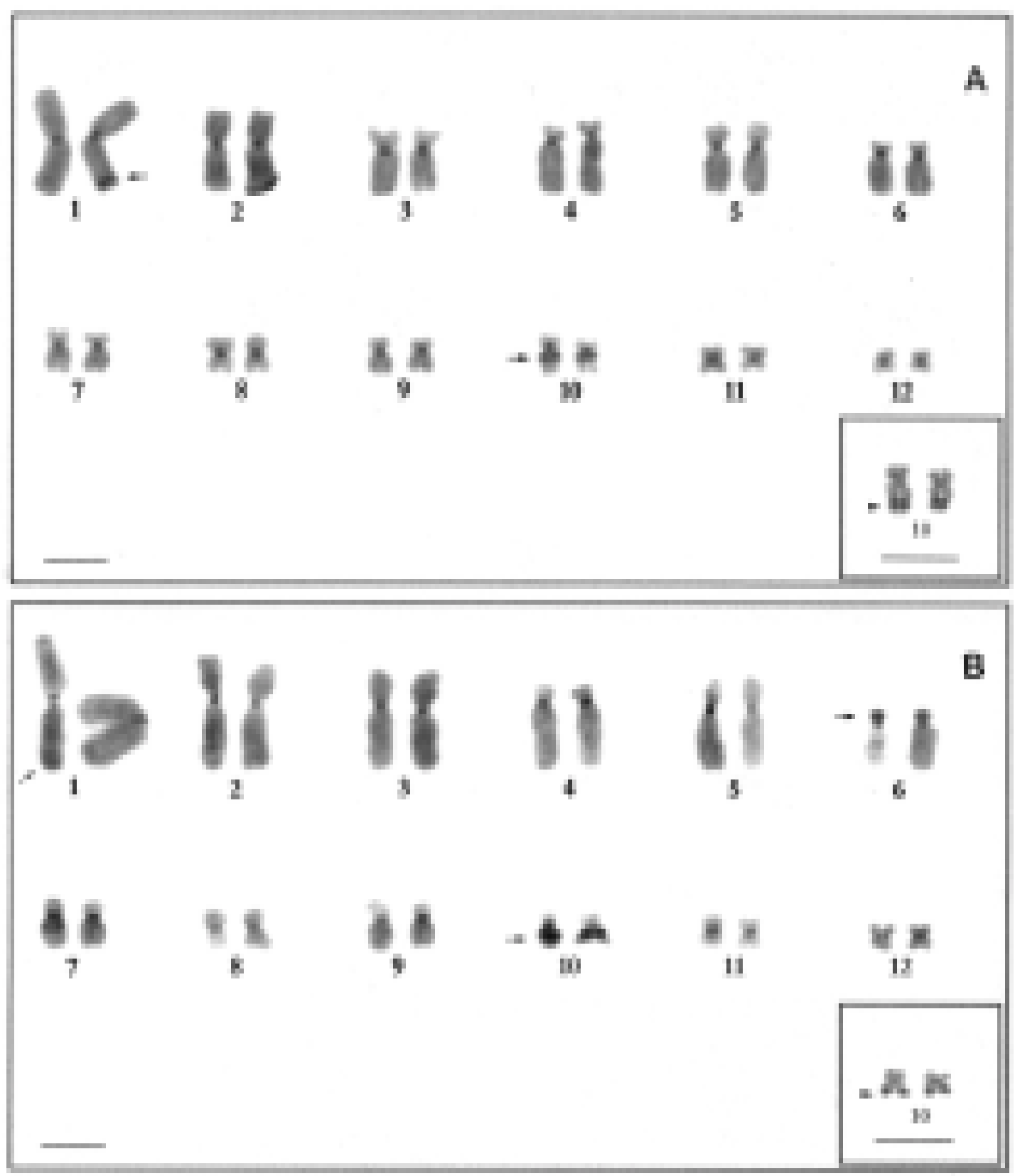

Figure 2 - C-banded metaphases of Hyla guentheri (A) and H. b. bischoffi (B). Inset: silver-stained NOR on the long arm of chromosome pair 10 . Bar $=5 \mathrm{~mm}$

pulchella group (Ananias 1996). Indeed, comparison of the chromosomal morphology of $H$. bischoffi and $H$. guentheri with the karyotypes of other species in the pulchella and polytaenia groups showed that they are quite similar. 

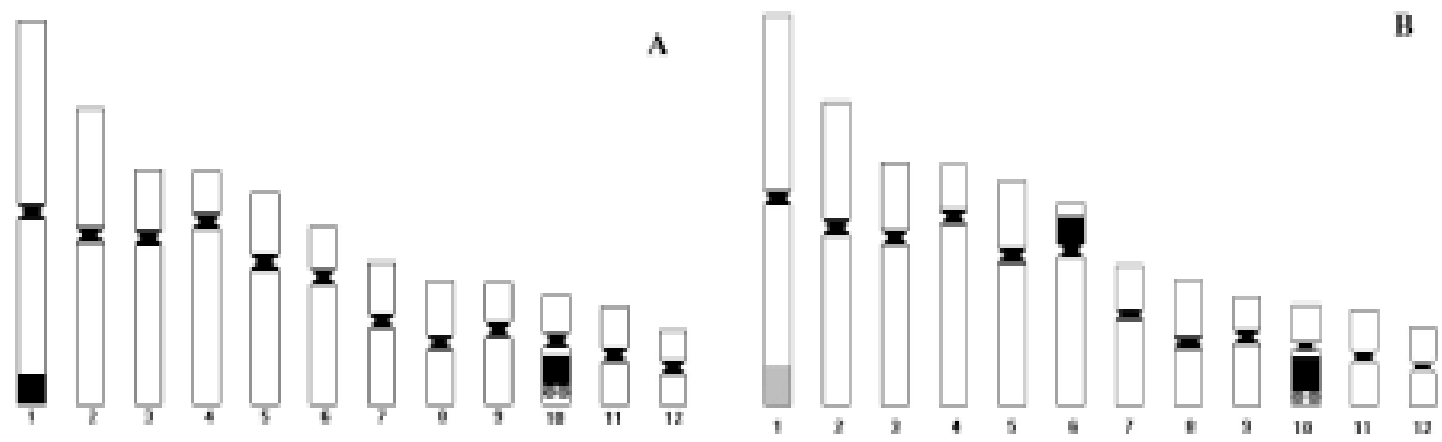

Figure 3 - Idiograms of Hyla guentheri (A) and H. b. bischoffi (B) karyotypes. Black areas denote dark C-bands, gray areas denote faint $\mathrm{C}$-bands and hatched circles represent the NORs.

Beçak (1968) classified chromosomes 1, 9, 10,11 and 12 of $H$. multilineata $(H . b$. multilineata) specimens collected in Itapecerica da Serra, state of São Paulo, as metacentric and the remaining as submetacentric. This differed from the classification of chromosomes 2, 4, 6, 8,9 and 10 obtained in the present paper. Comparison of our data for $H$. b. bischoffi with those of Foresti (1972) for a population of $H$. bischoffi from Rio dos Cedros, state of Santa Catarina, showed that the diploid number was the same $(2 n=24)$, but that chromosomes 2,4 , 6,9 and 10 were classified differently by the latter author. This discrepancy is attributable to the use of a different classification criteria since the chromosomes in all of these karyotypes have the same morphology.

The number and morphology of the chromosomes in Hyla b. bischoffi and $H$. guentheri were also similar to those of $H$. polytaenia (Rabello 1970). However, the location of the NORs and heterochromatin in $H$. polytaenia was not studied and a more detailed comparison cannot be made. On the other hand, the karyotype of $H$. b. bischoffi differed from those of Hyla pulchella, H. p. joaquini, $H$. caingua and $H$. prasina, species of the pulchella group (Ananias 1996), in chromosome number and morphology, and by the presence of a block of heterochromatin in the long arm of chromosome 10. This C-heterochromatin, which was also seen in the same chromosome pair of H. marginata, H. semiguttata and Hyla sp.n. (aff. semiguttata) (Ananias et al. 2004) and other species of the pulchella group (Ananias 1996), seems to be an important marker for this group.

In both species studied here, the NORs occurred at the region of the secondary constriction of the long arm of chromosome 10. An NOR-bearing chromosome 10 was also observed in H. marginata and Hyla sp.n. (aff. semiguttata) (Ananias et al. 2004). In the pulchella group, the NOR was located on chromosome pair 12 in $H$. prasina and $H$. pulchella, on chromosome pair 7 in $H$. caingua and on chromosome pair 1 in $H$. p. joaquini (Ananias 1996). There is no information on the NOR in the group polytaenia. Considering that the karyotypes of $H$. b. bischoffi and $H$. guentheri are conserved and they are very closely related species, the variation in the location of the NORs among them and the species $H$. prasina and $H$. pulchella suggests that chromosomal rearrangements, such as translocations, may have occurred during the evolution and differentiation of these species. According to Schmid (1978, 1982), the NOR almost always occurs at the same chromosomal location in the karyotypes of species of the same group or in groups of related species. Exceptions to this rule indicate that 
chromosomal rearrangements may have contributed to the species evolution (Schmid 1978).

The C-banded chromosomes of $H$. bischoffi and $H$. guentheri revealed a small amount of heterochromatin at the pericentromeric regions. Although the distribution of heterochromatin was very similar in the two species, $H$. bischoffi showed a specific band on chromosome 6, which was not seen in $H$. guentheri or other species of the $H$. pulchella group (Ananias 1996). This band may serve as a possible marker for $H$. bischoffi species.

Specimens of $H$. joaquini from a population at Urubici, state of Santa Catarina (Ananias 1996), showed the same pattern of heterochromatin distribution as that of the species analysed here, especially that of $H$. guentheri, with a small amount of heterochromatin at the pericentromeric regions and an interstitial band on chromosome 10 .

As shown above, the number and morphology of the chromosomes, the amount and distribution of heterochromatin and the presence of an interstitial band on chromosome 10 were shared by $H$. guentheri and $H$. bischoffi and all species analysed of the $H$. pulchella group. These findings indicate that, cytogenetically, the two species cannot be excluded from the $H$. pulchella group. The cytogenetic description of species in the $H$. polytaenia group, as recently defined by Cruz and Caramaschi (1998), may help to elucidate the relationships among the two species studied here and those two hylid groups.

\section{Acknowledgements}

The authors thank CAPES for financial support. PCAG was the recipient of a fellowship from FAPESP (Proc. 98/06087-9). The specimens were collected under a permit from the Instituto Brasileiro do Meio Ambiente e Recursos Naturais Renováveis (IBAMA nº. 002792/98-03 AC and 02001.002792/98-03 AC, licences 095/98 and 128/99 DIFAS).

\section{References}

Ananias, F. 1996. Caracterização cromossômica de espécies e subespécies do grupo pulchella (Amphibia, Anura, Hylidae). Unpublished M.Sc. Dissertation. Universidade Estadual de Campinas, Brazil.

Ananias, F., P. C. A. Garcia and S. M. Recco-Pimentel. 2004. Conserved karyotypes in the Hyla pulchella species group (Anura: Hylidae). Hereditas 140: 42-48.

Beçak, M. L. 1968. Chromosomal analysis of eighteen species of Anura. Caryologia 21: 191-208.

Bogart, J. P. 1973. Evolution of anuran karyotypes. Pp. 337-349 in J. L. Vial (Ed.), Evolutionary Biology of Anurans. Columbia. University of Missouri Press.

Braun, P. C. and C. A. S. Braun. 1977. Nova espécie de Hyla do Estado do Rio Grande do Sul, Brasil (Anura, Hylidae). Revista Brasileira de Biologia 37: 853-857.

Braun, P. C. and C. A. S. Braun. 1980. Lista prévia dos anfíbios do Estado do Rio Grande do Sul, Brasil. Iheringia, Série Zoologia 56: 121-146.

Cochran, D. M. 1955. Frogs of Southeastern Brazil. United States National Museum Bulletin 206: 1-423.

Cruz, C. A. G. and U. Caramaschi. 1998. Definição, composição e distribuição geográfica do grupo de $H y l a$ polytaenia Cope, 1870 (Amphibia, Anura, Hylidae). Boletim do Museu Nacional 392: 1-19.

Duellman, W. E., I. De la Riva and E. R. Wild. 1997. Frogs of the Hyla armata and Hyla pulchella groups in the Andes of South America, with definitions and analyses of phylogenetic relationships of Andean groups of Hyla. Scientific Papers of the Natural History Museum, University of Kansas 3: 1-41.

Faivovich, J., P. C. A. Garcia, F. Ananias, L. Lanari, N. Basso, and W. Wheeler. A molecular perspective of the phylogeny of the Hyla pulchella species group (Anura, Hylidae). Molecular Phylogenetics and Evolution. (In press.)

Foresti, F. 1972. Aspectos cromossômicos da família Hylidae (Amphibia - Anura). Unpublished M.Sc. Dissertation. Universidade de São Paulo, ESALQ, Brazil.

Garcia, P. C. A. 2003. Revisão taxonômica e análise filogenética das espécies do gênero Hyla Laurenti do complexo marginata/semiguttata (Amphibia, Anura, Hylidae). Unpublished Ph.D. Thesis. Universidade Estadual Paulista, Rio Claro, Brazil.

Green, D. M. and S. K. Sessions. 1991. Nomenclature for chromosomes. Pp. 431-432 in D. M. Green and S. K. Session (eds.), Amphibian Cytogenetics and Evolution. San Diego. Academic Press.

Haddad, C. F. B and I. Sazima. 1992. Anfíbios anuros da Serra da Japi. Pp. 188-211 in L. P. C. Morellato (ed.). 
História Natural da Serra do Japi - ecologia e preservação de uma área florestal no sudeste do Brasil. Campinas. UNICAMP/FAPESP.

Heyer, W. R., A. S. Rand, C. A. G. Cruz, O. L. Peixoto, and C. E. Nelson. 1990. Frogs of Boracéia. Arquivos de Zoologia, São Paulo 31: 231-240.

Howell, W. M and D. A. Black 1980. Controlled silverstaining of nucleolus organizer regions with a protective colloidal developer: 1-step method. Experientia 36: 1014-1015.

Klappenbach, M. A. and J. A. Langone. 1992. Lista sistematica y sinonimica de los anfibios del Uruguay. Anales del Museo Nacional de Historia Natural de Montevideo 2: 163-222.

Langone, J. A. 1997. Caracterizacion de Hyla guentheri Boulenger 1886 (Amphibia, Anura, Hylidae). Cuadernos de Herpetologia 11: 13-20.
Lutz, B. 1973. Brazilian Species of Hyla. Austin and London. University of Texas Press. 260 pp.

Rabello, M. N. 1970. Chromosomal studies in Brazilian anurans. Caryologia 23: 45-59.

Schmid, M. 1978. Chromosome banding in Amphibia. I. Constitutive heterochromatin and nucleolus organizer regions in Bufo and Hyla. Chromosoma 66: 361-388.

Schmid, M. 1982. Chromosome banding in Amphibia. VII. Analysis of the structure and variability of NORs in Anura. Chromosoma 87: 327-344.

Schmid, M., J. Olert and C. Klett. 1979. Chromosome banding in Amphibia. III. Sex chromosomes in Triturus. Chromosoma 71: 29-55.

Sumner, A. T. 1972. A simple technique for demonstrating centromeric heterochromatin. Experimental Cell Research 75: 304-306. 